\title{
First record of the genus Pseudopilolabus Legalov, 2003 (Coleoptera: Attelabidae) in Dominican amber
}

\author{
G. Poinar Jr. ${ }^{1}$, A. E. Brown ${ }^{2}$, and A. A. Legalov ${ }^{3}$ \\ ${ }^{1}$ Department of Integrative Biology, Oregon State University, Corvallis, OR 97331, USA \\ ${ }^{2} 629$ Euclid Avenue, Berkeley, CA 94708, USA \\ ${ }^{3}$ Institute of Systematics and Ecology of Animals, Siberian Branch, Russian Academy of Sciences, \\ Frunze Street 11, Novosibirsk 630091, Russia \\ Correspondence to: G. Poinar Jr. (poinarg@science.oregonstate.edu)
}

Received: 25 August 2015 - Revised: 30 October 2015 - Accepted: 30 October 2015 - Published: 17 November 2015

\begin{abstract}
A new weevil species (urn:Isid:zoobank.org: act:2D5E9E4A-A250-4D0A-AF69-CF4753436686), Pseudopilolabus othnius Poinar, Brown and Legalov, sp. nov. (Coleoptera: Attelabidae), is described from Dominican amber. The new species is close to the extant $P$. viridanus (Gyllenhal, 1839) and P. splendens (Gyllenhal, 1839) but differs by having a bronzed body, narrower and more convex elytral intervals, long antennae reaching the middle of the pronotum, and weakly convex eyes; from $P$. rugiceps (Voss, 1925) it differs by having a smoother pronotum without transverse rugosity; from P. chiriquensis (Hamilton, 1994) it differs by having indistinctly protuberant humeri and the elytra nearly parallel from the humeri to the midpoint. The fossil weevil is the first record of the tribe Pilolabini (Attelabidae) from the West Indies and the first record of the Attelabidae from any amber source.
\end{abstract}

\section{Introduction}

The leaf-rolling weevils of the family Attelabidae comprise a monophyletic group of curculionoid beetles adapted to roll leaves to provide food and protection for their larvae (Zuppa et al., 1994; Legalov, 2005b). Almost 1300 species are in the modern fauna (Legalov, 2007, 2010). Centers of their biodiversity are in the Oriental, Neotropical and Ethiopian regions. Fossil Attelabidae are rare (Legalov, 2015), with the oldest a Paleocene species from the Menat of France (Piton, 1940; Legalov, 2015). Representatives of the tribe Euscelini are known from the late Eocene of Florissant (Scudder, 1893; Legalov, 2007). One species of the extant Orien- tal genus Phialodes Roelofs, 1874 was described from upper Miocene deposits at Oeningen in Germany (Heer, 1865; Legalov, 2013). Two genera of the subtribe Paramecolabina Legalov, 2003, were described from the middle Miocene of China (Zhang, 1989; Zhang et al., 1994). Since members of the Attelabidae have not been found in any amber deposits (Hieke and Pietrzeniuk, 1984; Legalov 2015), the present record of a representative of the most primitive tribe of the Attelabidae in Dominican amber is very surprising.

\section{Material and methods}

The specimen was obtained from an amber mine in the Cordillera Septentrional of the Dominican Republic. Dating of Dominican amber is controversial, with the latest purported age of 20-15 Mya based on foraminifera (IturraldeVinent and MacPhee, 1996) and the earliest of 45-30 Mya based on coccoliths (Schlee, 1990). In addition, Dominican amber is secondarily deposited in sedimentary rocks, which makes a definite age determination difficult (Poinar Jr. and Mastalerz, 2000). A range of ages for Dominican amber is possible as the amber is associated with turbiditic sandstones of the upper Eocene to lower Miocene Mamey Group (Draper et al., 1994). Dominican amber was produced by the leguminous tree Hymenaea protera Poinar (Poinar Jr., 1991), and a reconstruction of the Dominican amber forest based on amber fossils indicated that the environment was similar to that of a present-day tropical moist forest (Poinar Jr. and Poinar, 1999). 


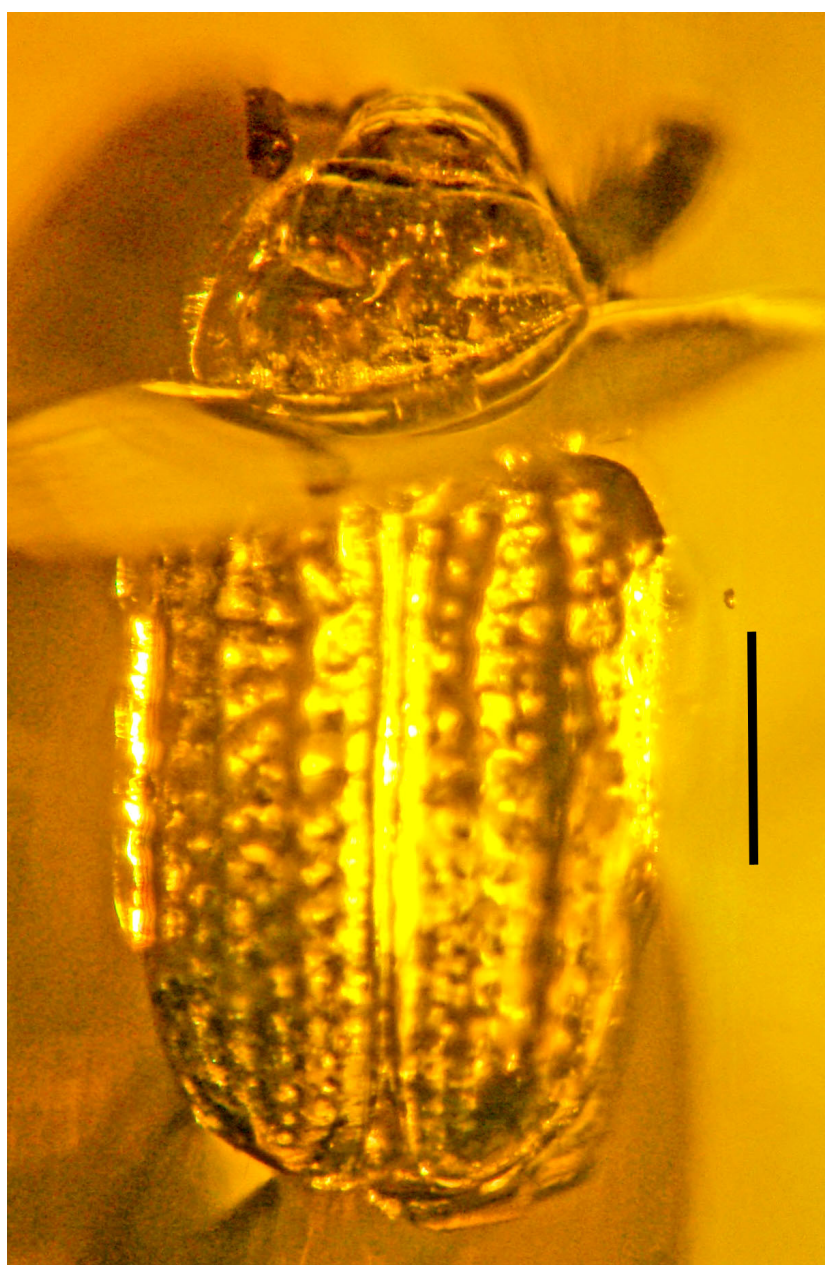

Figure 1. Dorsal view of Pseudopilolabus othnius sp. nov. in Dominican amber. Bar: $0.7 \mathrm{~mm}$.

\section{Systematic paleontology}

Family: Attelabidae Billberg, 1820

Subfamily: Attelabinae Billberg, 1820

Tribe: Pilolabini Voss, 1925

Genus: Pseudopilolabus Legalov, 2003

Pseudopilolabus othnius sp. nov.

Etymology: The specific epithet is taken from the Greek othneios, meaning strange, alien.

Holotype: Male, deposited in the Poinar amber collection (accession \# CW-161) maintained at Oregon State University, Corvallis, Oregon.

Type locality: Amber mine in the northern portion of the Dominican Republic.

Diagnosis: The new species is close to the extant $P$. viridanus (Gyllenhal, 1839) and P. splendens (Gyllenhal, 1839) from Mexico, but differs by having a bronzed body, narrower and more convex elytral intervals, long antennae reaching the middle of the pronotum, and weakly convex eyes; from

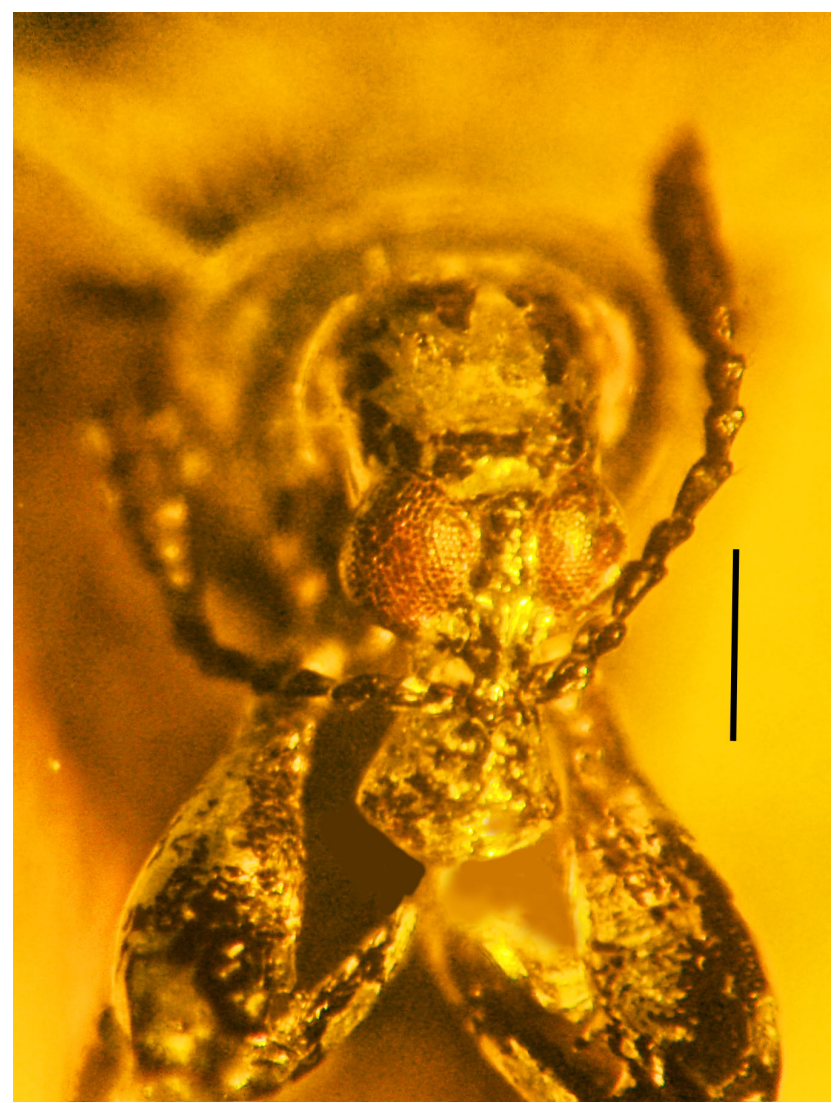

Figure 2. "En face" view of Pseudopilolabus othnius sp. nov. in Dominican amber. Bar: $0.4 \mathrm{~mm}$.

P. rugiceps (Voss, 1925) from Costa Rica it differs by having a smoother pronotum without transverse rugosity; from P. chiriquensis (Hamilton, 1994) from Panama it differs by having indistinctly protuberant humeri and the elytra nearly parallel from the humeri to the midpoint.

Remarks: The single gular suture, homonomous ventrites and claws lacking teeth that are connate at base, as well as tibiae with the uncus serrated on the inner edge (but lacking spurs), suggest placement in the family Attelabidae. The elytra with scutellar striae, head without a groove in front of the neck and pronotum without a distinct pronotal groove suggest placement in the subfamily Attelabinae. Placement of this species in the tribe Pilolabini is based on the triangular scutellum and long oval body with a metallic luster. The new species is placed in the genus Pseudopilolabus based on the elytra having regular punctate striae and smooth wide intervals.

Description (Figs. 1-4): Size: length of body (without rostrum), $3.7 \mathrm{~mm}$; length of rostrum, $0.4 \mathrm{~mm}$. Body long, oval, bronzed with metallic luster, without scales.

Head: without groove in front of the neck; rostrum short, 0.5 times as long as pronotum, equal in length and width at apex, 1.4 times longer than wide in middle, 1.8 times longer than wide at base, widened from base to apex, almost straight, with dense punctures; forehead narrow, flattened, punctured, 


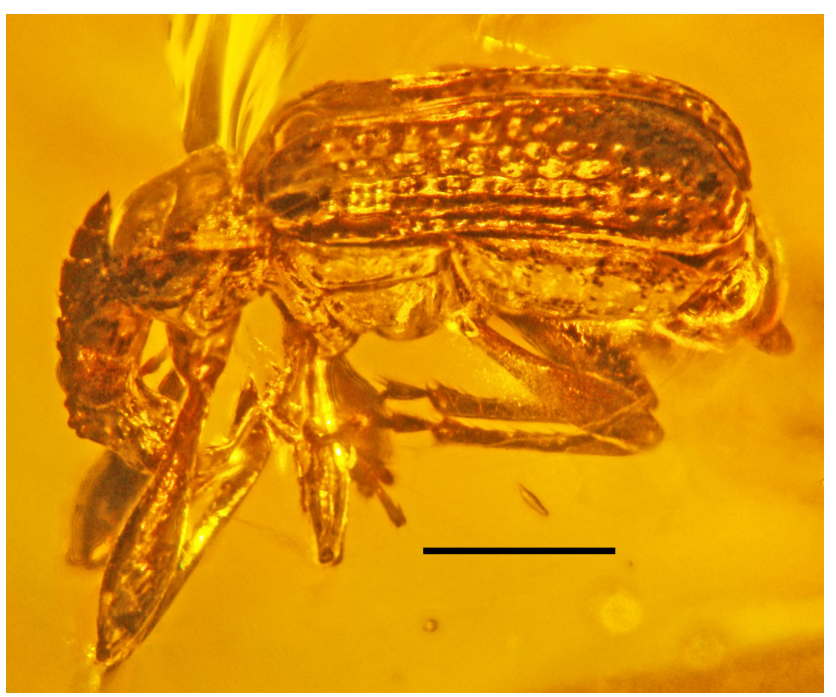

Figure 3. Lateral view of Pseudopilolabus othnius sp. nov. in Dominican amber. Bar: $1.0 \mathrm{~mm}$.

0.4 times as wide as rostral basal width; eyes large, 1.3 times longer than wide, rounded, protruding from the head contour, with transverse diameter 1.3 times as wide as rostral basal width; vertex weakly flattened, coarsely punctured; temples long, 1.1 times as long as eye; gular suture single; antennae inserted in middle of rostrum, reaching to middle of pronotum; scape short, 2.3 times longer than wide; funicle with first to seventh conical antennomeres; first antennomere 1.8 times longer than wide, 0.7 times as long and 0.9 times as wide as scape; second antennomere 2.3 times longer than wide, 1.3 times as long as and equal in width to first antennomere; third antennomere 1.9 times longer than wide, 0.7 times as long and 0.9 times as wide as second antennomere; fourth antennomere 2.1 times longer than wide, 1.3 times as long as and 1.1 times as wide as third antennomere; fifth antennomere 1.9 times longer than wide, 0.9 times as long as and equal in width to fourth antennomere; sixth antennomere 1.4 times longer than wide, 0.9 times as long and 1.1 times as wide as fifth antennomere; seventh antennomere 0.9 times longer than wide, 1.2 times as long as and 1.2 times as wide as sixth antennomere; club compact, 3.3 times longer than wide, 0.9 times as long as funicle; first club article equal in length and width, 1.5 times as long and 1.3 times as wide as seventh antennomere; second club article 0.9 times longer than wide, 0.9 times as long as and equal in wide as first club article; third club article 1.4 times longer than wide, 1.3 times as long and 0.8 times as wide as second club article.

Pronotum: bell-shaped; 1.1 times longer than wide at apex, 0.8 times longer than wide in middle and at base; without distinct pronotal groove; disk weakly flattened, narrowed at apex, rarely and finely punctured; distance between punctures much larger than diameter of punctures; scutellum triangular, flattened.

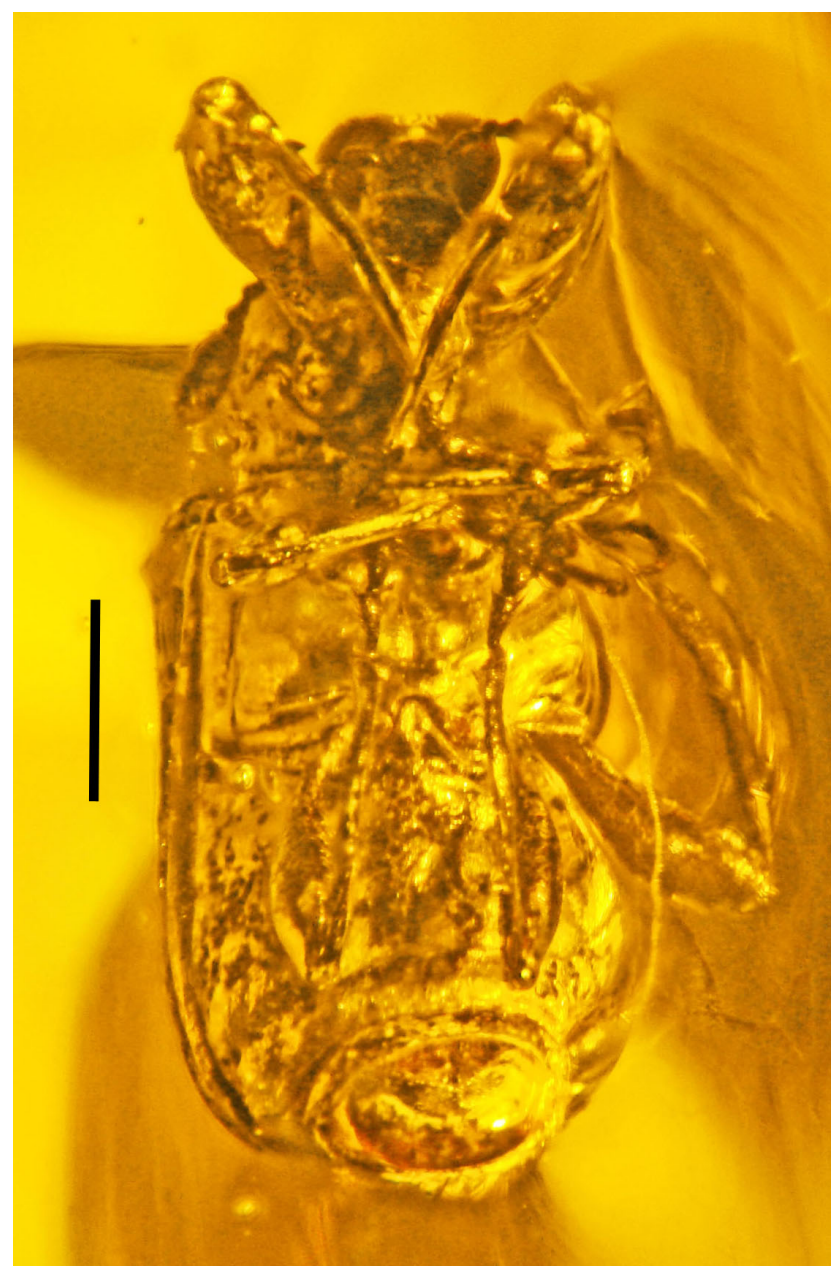

Figure 4. Ventral view of Pseudopilolabus othnius sp. nov. in Dominican amber. Bar: $0.7 \mathrm{~mm}$.

Elytra: with scutellar striae; elongated and weakly convex, 1.4 times longer than wide at base and in middle, 1.8 times longer than wide at apical fourth, 2.6 times as long as pronotum; greatest width at humeri and middle, elytral base 1.4 times as wide as pronotal basal width; humeri weakly convex; punctate striae regular; intervals weakly flattened, almost smooth and wide, 1.3-2.0 times as wide as striae; apex of elytra rounded.

Thorax: weakly punctured; postocular lobes absent; precoxal portion of prosternum short, 0.3 times as long as procoxa length; procoxal cavities connected; postcoxal portion of prosternum 1.3 times as long as precoxal portion and 0.4 times as long as procoxa length; middle coxal cavities quite narrowly separated; metathorax 1.3 times as long as metacoxa length; metepisternum wide, 3.6 times longer than wide in middle.

Abdomen: convex ventrally, densely punctured; ventrites almost homologous; first ventrite 1.2 times as long as metacoxa length; second ventrite 0.9 times as long as first ventrite; third ventrite 0.8 times as long as second ventrite; fourth ventrite 
0.9 times as long as third ventrite; fifth ventrite 0.5 times as long as fourth ventrite. Pygidium exposed beyond elytra. Legs: long; procoxae conical; mesocoxae spherical; metacoxae transverse; femora weakly clavate, without teeth; profemora 4.4 times longer than wide in middle; mesofemora 4.6 times longer than wide; metafemora 4.8 times longer than wide; tibiae straight, with uncus, without spurs, serrate on inner edge; protibiae 11.0 times longer than wide in middle; metatibiae 9.5 times longer than wide in middle; tarsi long; first to second tarsomeres conical; third tarsomere bilobed; fifth tarsomere elongate; tarsomeres with pulvilli on underside; metatarsus: first tarsomere 2.4 times longer than wide at apex; second tarsomere 1.3 times longer than wide at apex, 0.8 times as long and 1.4 times as wide as first tarsomere; third tarsomere 0.9 times longer than wide at apex, equal in length and 1.4 times as wide as second tarsomere; fifth tarsomere 4.3 times longer than wide at apex, 1.9 times as long and 0.4 times as wide as third tarsomere; claws connate at base, without teeth.

\section{Discussion}

The tribe Pilolabini occurs in Central America (Hamilton, 1994) and is the most primitive in the family based on the unique apical structure of the tibiae with the mucro and uncus located on different sides of the tibial apex in females (Legalov, 2005a). Representatives of this tribe are not known in Hispaniola (Perez-Gelabert, 2007) or the entire West Indies (O'Brien and Wibmer, 1982). Two genera (Pilolabus Jekel, 1860 and Pseudopilolabus Legalov, 2003) have been assigned to this tribe (Legalov, 2007). The first genus, consisting of eight Mexican species, is characterized by onejointed labial palpi, body with dense, appressed setae and the transfer apparatus consisting of one sclerite located at the bottom of the endophallus (Hamilton, 1994, Figs. 5, 9, 10, 12, 13). Pseudopilolabus, which is distributed from Mexico to Panama, differs by having two-jointed labial palpi, a naked body with metallic luster, and the transfer apparatus consisting of two sclerites located in the bottom third of the endophallus (Hamilton, 1994, Figs. 2, 4, 6-8). Species of this genus are more numerous in collections (Hamilton, 1994).

This family of weevils is unusual in that many of the females show sophisticated behavior in caring for their young. This is especially true with those species that lay their eggs in self-made nests inside rolled up leaves. While most members of the family are tropical, some occur in eastern North America and have been observed making "nests" for their young (Blatchley and Leng, 1916). In some species, the female beetles go to much trouble severing portions of the leaves so they will fold inward and enclose a mass of plant material that serves as food for the young. The larvae develop in these compact, thimble-shaped leaf rolls that often remain hanging on the tree by a narrow strip of leaf tissue. The larvae pupate in the "nest" that either remains on the tree or falls to the ground. A number of tree species are involved, including oaks, alders, walnuts, butternuts, hickories, sumacs and hazelnuts. It is curious that there are no records of these beetles developing in leaves of herbivorous plants. Other members of this weevil family deposit eggs in fruit and buds; however these beetles are too scarce to cause serious damage to forest trees (Craighead, 1950).

The discovery of Pseudopilolabus othnius sp. nov. in Dominican amber adds another family of curculionid beetles to the Dominican amber fauna. Thus far, the families Belidae (Oxycoryninae) (Poinar Jr. and Legalov, 2014d), Rhynchitidae (Poinar Jr. and Legalov, 2015e), Brentidae (Apioninae (Poinar Jr. and Legalov, 2015c) and Brentinae (Poinar Jr., 2009)), Curculionidae (Molytinae (Poinar Jr. and Legalov, 2014b; Poinar Jr. and Voisin, 2003), Dryophthorinae (Davis and Engel, 2006c, 2009; Poinar Jr. and Legalov, 2014a), Cossoninae (Davis and Engel, 2006b, 2007a; Poinar Jr. and Legalov, 2015d), Baridinae (Davis and Engel, 2006a; Poinar Jr. and Legalov, 2014c; Poinar Jr. and Legalov, 2015b), Curculioninae (Poinar Jr. and Legalov, 2015a) and Entiminae (Poinar Jr. and Brown, 2011; Poinar Jr. et al., 2013)), Scolytidae and Platypodidae (Bright and Poinar Jr., 1994; Davis and Engel, 2007b) have been reported from this amber source. Pseudopilolabus othnius sp. nov. is the first record of the tribe Pilolabini (Attelabidae) from the West Indies and the first record of Attelabidae from any amber source. Based on this finding, when the fossil was living in the Miocene, there may have been a land bridge connecting Hispaniola and Central America, thus providing access for this genus throughout the entire territory (Sommer, 2009).

Acknowledgements. We are grateful to L. Chamorro (USA: Washington), J. Frisch (Germany: Berlin), O. Jaeger (Germany: Dresden), K.-D. Klass (Germany: Dresden), B. A. Korotyaev (Russia: St. Petersburg), P. Limbourg (Belgium: Brussels), S. W. Lingafelter (USA: Washington), and J. Willers (Germany: Berlin) for the opportunity to study comparative material of the tribe Pilolabini deposited in the Institut royal des Sciences naturelles de Belgique; Leibniz-Institut für Evolutions- und Biodiversitätsforschung, $\mathrm{Mu}$ seum für Naturkunde, Berlin; Museum für Tierkunde, Senckenberg Naturhistorische Sammlungen Dresden; Smithsonian Institution National Museum of Natural History; and Zoological Institute of the Russian Academy of Sciences.

The study was partially supported by the Federal Fundamental Scientific Research Programme for 2013-2020 (grant number VI.51.1.7) and the Russian Foundation for Basic Research (grant number 15-04-02971a).

Edited by: D. Korn

Reviewed by: C. O'Brien and A. Kirejtshuk 


\section{References}

Blatchely, W. S. and Leng, C. W.: Rhynchophora or weevils of North Eastern America, The Nature Pub. Co., Indianapolis, 1682, 1916.

Bright, D. E. and Poinar Jr., G. O.: Scolytidae and Platypodidae (Coleoptera) from Dominican amber, Ann. Entomol. Soc. Amer., 87, 170-195, 1994.

Craighead, F. C.: Insect enemies of Eastern Forests, U.S. Dept. Agr. Miscell. Pub. 657. U. S. Govt. Printing Office, Washington, D. C., 1-679, 1950.

Davis, S. R. and Engel, M. S.: A zygopine weevil in Early Miocene amber from the Dominican Republic (Coleoptera; Curculionidae), Caribbean J. Sci., 42, 255-257, 2006a.

Davis, S. R. and Engel, M. S.: A weevil of the genus Caulophilus in Dominican amber (Coleoptera: Curculionidae), Polsk. Pismo Entomol., 75, 101-104, 2006b.

Davis, S. R. and Engel, M. S.: Dryophthorine weevils in Dominican amber (Coleoptera: Curculionidae), Trans. Kans. Acad. Sci., 109, 191-198, 2006c.

Davis, S. R. and Engel, M. S.: Cossonine weevils in Dominican amber (Coleoptera: Curculionidae), Linzer Biol. Beitr., 39, 803820, 2007a.

Davis, S. R. and Engel, M. S.: A new ambrosia beetle in Miocene amber of the Dominican Republic (Coleoptera: Curculionidae: Platypodinae), Alavesia, 1, 121-124, 2007b.

Davis, S. R. and Engel, M. S.: An orthognathine weevil of the genus Mesocordylus in Dominican amber, Beitr. Entomol., 59, 233238, 2009.

Draper, G., Mann, P., and Lewis, J. F.: Hispaniola, 129-150, in: Caribbean Geology: An introduction, edited by: Donovan, S. and Jackson, T. A., University West Indies Publishers' Association, Kingston, Jamaica, 1994.

Hamilton, R. W.: Revision of the new world genus Pilolabus Jekel (Coleoptera: Attelabidae), Trans. Amer. Entomol. Soc., 120, 369-411, 1994.

Heer, O.: Die Urwelt der Schweiz, Zurich, F. Schulthess Verlag, 1865.

Hieke, F. and Pietrzeniuk, E.: Die Bernstein-Käfer des Museums für Naturkunde, Berlin (Insecta, Coleoptera), Mitt. Zool. Museum Berlin, 60, 297-326, 1984.

Iturralde-Vinent, M. A. and MacPhee, R. D. E.: Age and Paleogeographic origin of Dominican amber, Science, 273, 1850-1852, 1996.

Legalov, A. A.: Reconstruction of phylogeny in leaf-rolling weevils (Coleoptera, Rhynchitidae, Attelabidae) using the SYNAP method, Report, Zoologichesky Zhurnal, 84, 190-194, 2005a.

Legalov, A. A.: Trophic relations of leaf-rolling weevils (Coleoptera, Rhynchitidae, Attelabidae), Zool. Zh., 84, 352-361, 2005b.

Legalov, A. A.: Leaf-rolling weevils (Coleoptera: Rhynchitidae, Attelabidae) of the world fauna, Novosibirsk: Agro-Siberia, 2007.

Legalov, A. A.: Contribution to the knowledge of the leaf-rolling weevils (Coleoptera, Rhynchitidae, Attelabidae), Amur. Zool. J., 2, 13-38, 2010.

Legalov, A. A.: New and little known weevils (Coleoptera: Curculionoidea) from the Paleogene and Neogene, Historical Biology, 25, 59-80, doi:10.1080/08912963.2012.692681, 2013.
Legalov, A. A.: Fossil Mesozoic and Cenozoic weevils (Coleoptera, Obrienioidea, Curculionoidea), Paleontol. J., 49, 1442-1513, doi:10.1134/S0031030115130067, 2015.

O'Brien, C. W. and Wibmer, G. J.: Annotated checklist of the weevils (Curculionidae sensu lato) of North America, Central America, and the West Indies (Coleoptera: Curculionoidea), Mem. Amer. Entomol. Inst., 34, 1-382, 1982.

Perez-Gelabert, D. E.: Arthropods of Hispaniola (Dominican Republic and Haiti): a checklist and bibliography, Zootaxa, 1831, 1-530, 2007.

Piton, L.: Paléontologie du gisement Éocène de Menat (Puy-deDôme) (Flore et faune), Clermont-Ferrand: Imprimeries Paul Vallier, 1940.

Poinar Jr., G. O.: Hymenaea protera sp.n. (Leguminosae: Caesalpinoideae) from Dominican amber has African affinities, Experientia, 47, 1075-1082, 1991.

Poinar Jr., G. O.: Dominibrentus leptus, n. gen., n. sp. (Curculionoidea, Brentidae, Cyphagoginae, Dominibrentini, n. tribe), a straight snouted weevil in Dominican amber, Historical Biology, 21, 51-55, doi:10.1080/08912960903122807, 2009.

Poinar Jr., G. O. and Brown, A. E.: Descriptions of a broad-nosed weevil (Eudiagogini: Curculionidae) and false ladybird beetle (Nilionini: Nilionidae) in Dominican amber, Historical Biology, 23, 231-235, doi:10.1080/08912963.2010.527159, 2011.

Poinar Jr., G. and Legalov, A. A.: Bicalcasura maculata n. gen., n. sp. (Curculionoidea: Dryopthtoridae) with a list of weevils described from Dominican amber, Historical Biology, 26, 449-453, doi:10.1080/08912963.2013.786066, 2014a.

Poinar Jr., G. and Legalov, A. A.: New Cryptorhynchinae (Coleoptera: Curculionidae) in Dominican amber, Historical Biology, 26, 502-534, doi:10.1080/08912963.2013.797971, 2014b.

Poinar Jr., G. and Legalov, A. A.: New species of the subfamily Conoderinae (Coleoptera: Curculionidae) in Dominican amber, Historical Biology, 26, 556-562, doi:10.1080/08912963.2013.802311, 2014c.

Poinar Jr., G. and Legalov, A. A.: Pleurambus strongylus n. gen., n. sp. (Coleoptera: Belidae) in Dominican amber, Historical Biology, 26, 670-674, doi:10.1080/08912963.2013.829825, 2014d.

Poinar Jr., G. and Legalov, A. A.: New Curculioninae (Coleoptera: Curculionidae) in Dominican amber, Palaeontol. Electron., 18, 13A, 1-15, 2015a.

Poinar Jr., G. and Legalov, A. A.: First record of the genus Baris Germar, 1817 (Coleoptera: Curculionidae), in Dominican amber, Foss. Rec., 18, 31-35, doi:10.5194/fr-18-31-2015, 2015b.

Poinar Jr., G. and Legalov, A. A.: New Apioninae (Coleoptera: Brentidae) in Dominican amber, Historical Biology, 27, 134157, doi:10.1080/08912963.2013.871010, 2015c.

Poinar Jr., G. and Legalov, A. A.: New species of the subfamily Cossoninae (Coleoptera: Curculionidae) in Dominican amber, Historical Biology, 27, 491-502, doi:10.1080/08912963.2014.888422, 2015d.

Poinar Jr., G. and Legalov, A. A.: Two new species of the genus Rhynchitobius Sharp, 1889 (Coleoptera: Rhynchitidae) in Dominican amber, Ann. Société Entomol. France (N.S.), 51, 70-77, doi:10.1080/00379271.2015.1059996, 2015e.

Poinar Jr., G. O. and Mastalerz, M.: Taphonomy of fossilized resins: determining the biostratinomy of amber, Acta Geol. Hisp., 35, 171-182, 2000. 
Poinar Jr., G. O. and Poinar, R.: The Amber forest, Princeton, NJ, Princeton University Press, 1999.

Poinar Jr., G. O. and Voisin, J. F.: A Dominican amber weevil, Velatis dominicana gen. n., sp. n. and key to the genera of the Anchonini (Molyitinae, Curculionidae), Nouv. Rev. Entomol., 19, 373-381, 2003.

Poinar Jr., G., Legalov, A. A., and Brown, A. E.: Brachycamacina, a new subtribe of the tribe Naupactini (Coleoptera: Curculionidae: Entiminae) in Dominican amber, Palaeontol. Electron., 16, 24A, 1-9, 2013.

Schlee, D.: Das Bernstein-Kabinett, Begleitheft Bernsteinausstellung Museum Löwentor, Stuttgart, 28, 1-100, 1990.

Scudder, S. H.: Tertiary Rhynchophorus Coleoptera of the United States, Mon. U.S. Geol. Survey, 21, 1-206, 1893.
Sommer, M.: Late Cretaceous to Miocene tectonic reconstruction of the northwestern Caribbean - regional analysis of Cuban geology, $\mathrm{PhD}$ thesis (Universität Greifswald) (urn:nbn:de:gbv:9-000669-5; http://ub-ed.ub.uni-greifswald.de/ opus/volltexte/2009/669/), last access: 9 October 2009.

Zhang, J.: Fossil insects from Shanwang, Shandong, China, Jinan. Shandong Sci. Techn. Publ., 1989.

Zhang, J., Sun, B., and Zhang, X.: Miocene Insects and Spinders from Shanwang, Shandong, Beijing, 1994.

Zuppa, A., Osella, G., and Biondi, S.: Parental care in Attelabidae (Coleoptera, Curculionoidea), Ethology Ecol. Evol., 3, 113-118, 1994. 